UDC 681.3.01

DOI: 10.15587/2706-5448.2021.229636

Article type «Reports on Research Projects»

\section{Yana Biletska, Valeriia Papakina, Natalia Danko, Larisa Grigorova-Berenda}

\title{
DEVELOPMENT OF NUTRITION METHODOLOGY FOR ATHLETES IN A PANDEMIC CONDITION
}

The object of research is the diet, physical activity, individual and anthropogenic data of athletes-athletes. A systematic study of scientific literature and a systemic analysis of actual nutrition and sports load were carried out. On its basis, the problems of nutrition of athletes in a pandemic are analyzed and the ways of their solution are determined. During the research, the methods of theoretical analysis of literature, synthesis, formalization, abstraction and experimental studies of the actual nutrition and sports load of athletes-athletes were used.

As a result of the research carried out, a methodology of diets for athletes in a pandemic was developed, with its subsequent computerization on the basis of the $1 C$ «Enterprise» platform. This methodology is based on the creation of a database about a specific athlete. This allows in the future to calculate the individual requirements for energy and all nutrients, taking into account the medico-biological requirements for macro- and micronutrients, as well as biologically active substances in consumed food. The program selects the necessary traditional dishes and products, as well as specialized products necessary to fill all the needs of the body of a particular athlete.

All the necessary components for a full-fledged diet of an athlete have been analyzed and described. The necessity of eating behavior and the combination of a correct diet with an individual amount of loads have been determined. The methodology of the diet development process is presented. In comparison with analogues, the developed program takes into account the type and time of physical activity, controls the amount of water consumed, calculating an individual food ration, taking into account food preferences and allergic reactions.

The introduction of the developed methodology and the use of its computerized program is a rational approach to the diet of athletes in a pandemic, as evidenced by the accumulated experience and achievements of modern nutritional science. Combining a properly balanced diet with a training program will allow an athlete to improve their athletic performance in a pandemic.

Keywords: diet of athletes, diet methodology, nutrition programs, diet in a pandemic.

\section{How to cite}

Biletska, Y., Papakina, V., Danko, N., Grigorova-Berenda, L. (2021). Development of nutrition methodology for athletes in a pandemic condition. Technology Audit and Production Reserves, 2 (3 (58)), 37-39. doi: http://doi.org/10.15587/2706-5448.2021.229636

\section{Introduction}

Comprehensive researches of scientists and world statistics state the necessity and timeliness of the development of food rations for persons with individual characteristics of the organism, based on the state of health, working conditions, the intensity of mental and physical stress [1,2].

Analyzing the work [3-5], it is found that the directions of the development of rations for athletes both to a pandemic and during it, aimed at a balanced intake of proteins, fats, carbohydrates. Taking carbohydrates 3-4 hours before training increases liver and muscle glycogen and improves endurance performance.

In [6], the nutritional methodology for athletes is based on the concept, which is assessed by the total amount and time of daily consumption of carbohydrates in relation to physical activity. According to this methodology, computer programs have been developed «High carbohydrate availability», for intense exercise before the competition, and «Low carbohydrate availability», for daily exercise, or weight loss.

In medical publications $[7,8]$, the global pandemic is considered as a catalyst for an innovative approach to the development of the diet of athletes. It was determined that athletes belong to the segment of persons in need of nutrition, taking into account anthropogenic, individual data (gender, age, height, data on body composition) of the type and duration of physical activity. Taking into account the development directions highlighted in the UN project «Health of the Nation in the Fight Against COVID-19», the development of a dietary methodology for athletes is an urgent and timely task.

Based on research in the field of sports nutrition [9], it is possible to separate a new direction - the development and implementation of computer technologies to assess the nutrition of athletes. Scientists have developed nutritional methodologies, for ease of use they are systematized into a database in electronic form. 
Scientific interest was aroused by the «Athlete» program [10], developed by the National University of Physical Education and Sport in Ukraine (Ukraine). This program provides an opportunity to calculate an individualized diet of an athlete, taking into account the schedule of loads, the intensity of training, conducting a comparative analysis «before» and «after» the individualized nutrition. The peculiarity of the program lies in the optimization of proteins, fats and carbohydrates, taking into account the energy consumption during training of each athlete, but the disadvantage of the «Athlete» program is the inability to analyze and calculate the content of vitamins and microelements.

In work [11], a nutritional program «Test of rational nutrition» was developed, where more attention is paid to the analysis and calculation of the content of vitamins and microelements. The program provides data on the content of consumed vitamins and minerals. According to the developers, with the help of an individualized program, it is possible to avoid vitamin deficiency and micronutrient deficiencies.

The disadvantages of the above programs are inconsistency with the type of physical activity and their volume. Known programs do not control the amount of water consumed, food preferences and allergic reactions in food ingredients, which are necessary in conditions that have the ability to affect the decrease in the immune forces of the athlete's body.

In connection with the above, the development of a methodology for diets for athletes in a pandemic is an important scientific and applied problem. This vector for solving the problem is the most expedient, as evidenced by the accumulated experience and achievements of modern nutritional science. The solution of the above issues will help improve the health of athletes through a properly balanced diet with a training program. Which, of course, is socially necessary and economically beneficial, as it will allow athletes to adequately represent their country at the international level and save state budget funds intended for hospital deductions in case of illness on COVID-19.

Therefore, the aim of research is to develop a methodology for diets for athletes in a pandemic for its further computerization in accordance with the content of biologically irreplaceable components, personal data of a specific athlete, and the type of physical activity. This is possible by improving the $1 \mathrm{C}$ «Enterprise» program.

The object of research is the diet, physical activity, individual and anthropogenic data of athletes-athletes.

\section{Methods of research}

According to this aim, a systematic study of the scientific literature and a systemic analysis of the actual nutrition and sports load were carried out. On its basis, the problems of nutrition of athletes in a pandemic are analyzed and the ways of their solution are determined. During the research, the methods of theoretical analysis of the literature were used: generalization, synectics, formalization, abstraction [12]. As well as experimental studies of the actual nutrition and sports load of athletes-athletes. The research was carried out on the basis of the Tokari sanatorium (Lebedyn, Sumy region, Ukraine) within the framework of research theme No. 0119U10357 «Scientific development of health-improving nutrition technology» of V. N. Karazin Kharkiv National University (Ukraine).

\section{Research results and discussion}

The nutritional methodology for athletes in a pandemic is depicted in Fig. 1.

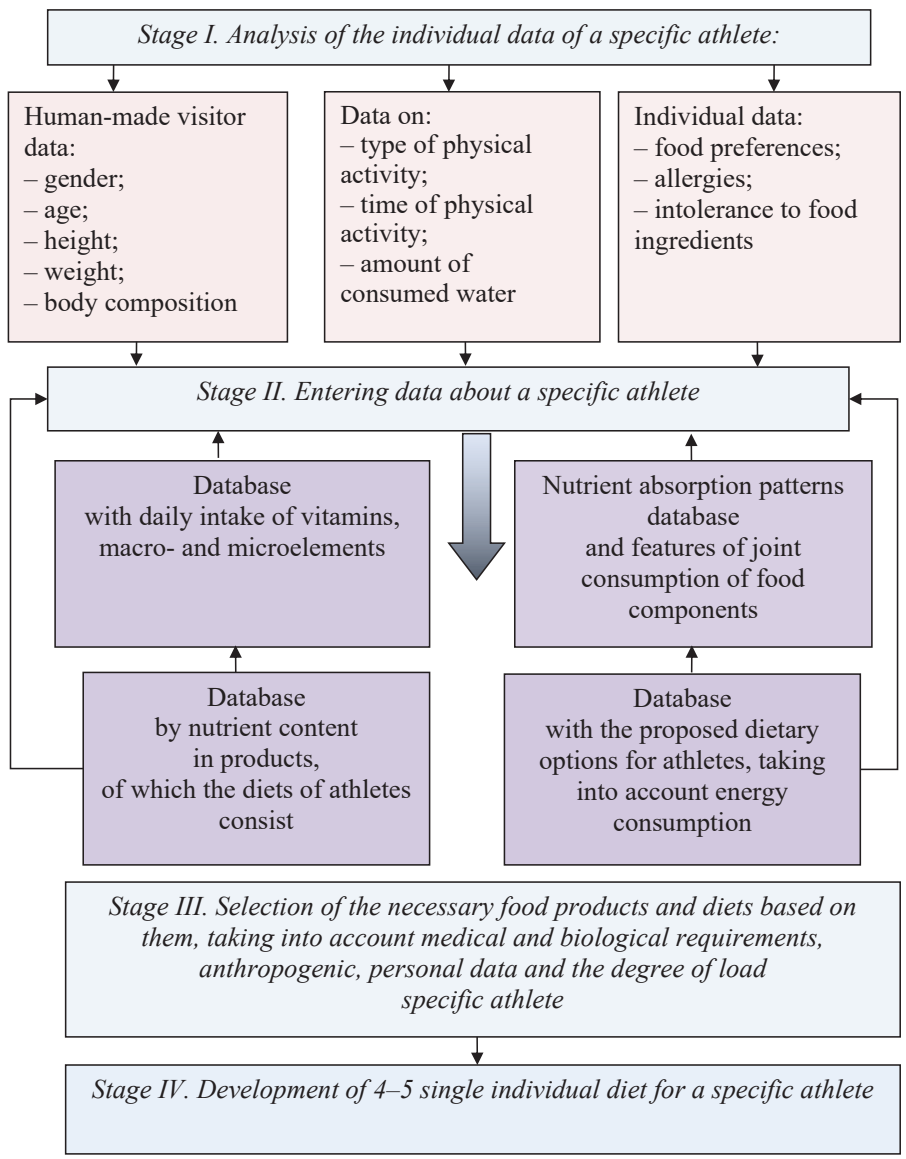

Fig. 1. Methodology of diets for athletes in a pandemic

According to the developed methodology of diets for athletes in a pandemic, it is necessary to analyze anthropogenic, individual data for the athlete whose diet is calculated.

A database about a specific athlete is being created, which allows to further calculate the individual needs for energy and all nutrients, taking into account the medicobiological requirements for macro- and micronutrients, as well as biologically active substances in consumed food products. The program selects the necessary traditional dishes and products, as well as specialized products necessary to fill all the needs of the body of a particular athlete.

At this stage, the technological base of ready-made dishes with their chemical composition and calorie content, as well as information about the cooking technology, is used. The technological base of dishes and products allows to quickly compose rations, replace dishes, calculate the necessary products, draw up a menu-layout, and prepare a dish technologically correctly. After that, the development of 4-5 single individual diet for a specific athlete is carried out according to the plan of the training process. The diet is compiled in accordance with the 
traditional nutritional system, which includes 4-5 meals a day. The diet consists of traditional dishes and products with a precisely calculated chemical composition, as well as specialized products.

The results obtained solve the existing scientific and applied problem was investigated. Thanks to the creation of a database about a specific athlete, analyzing not only anthropogenic data, but also individual data (history of allergic reactions, food preferences, etc.). The database is being optimized, which makes it possible to calculate diets with a biomedical approach to the athlete's state of health at the moment.

When implementing the developed methodology, it is necessary to take into account the degree of assimilation of nutrients and the peculiarities of joint consumption of food components. As the degree of absorption of nutrients varies with a decrease in the body's immune forces. From this perspective, it should be noted that the use of the proposed methodology should be implemented under the supervision of nutritionists. What cannot prevent the implementation of the methodology is that every sports school has such specialists.

\section{Conclusions}

The methodology of diets for athletes in a pandemic with its subsequent computerization is proposed. It consists in entering data about a specific athlete into a database block with an analysis of anthropogenic data (gender, age, height, weight, body composition), data on physical activity and the amount of water consumed and individual data (food preferences, allergies, intolerance to food ingredients). This allows the most accurate calculations in the database blocks from the daily intake of vitamins, macro- and microelements, taking into account energy consumption, the content of nutrients in the products of which the diets of athletes consist.

The characteristic features of the methodology are the development of the above databases and the optimization of data on the selection of the necessary food products and diets based on them, taking into account the medical and biological requirements for the athlete's health at the moment.

This application can solve the problem of improving the health of athletes through a properly balanced diet with a training program, which will allow athletes to adequately represent their country at the international level and save state budget funds intended for hospital deductions in case of illness on COVID-19.

\section{References}

1. Biletska, Y., Badyhina, H., Semeniuk, A. (2020). Development of an integrated method for implementation of food diets to medical and health institutions. Technology Audit and Production Reserves, 2 (4 (52)), 32-34. doi: http://doi.org/10.15587/23128372.2020 .199911
2. Biletska, Y., Djukareva, G., Nekos, A., Husliev, A., Krivtsova, A., Bakirov, M. et. al. (2020). Investigation of change of quality indicators of gluten-free bread during storage. Eastern-European Journal of Enterprise Technologies, 5 (11 (107)), 54-61. doi: http:// doi.org/10.15587/1729-4061.2020.215019

3. Marriott, B., Birt, D. F., Stallings, V. A., Yates, A. A. et. al. (Eds.) (2020). Present Knowledge in Nutrition. Volume 2: Clinical and Applied Topics in Nutrition. Academic Press, 646. doi: http:// doi.org/10.1016/c2018-0-02533-5

4. Hargreaves, M., Hawley, J. A., Jeukendrup, A. (2004). Preexercise carbohydrate and fat ingestion: effects on metabolism and performance. Journal of Sports Sciences, 22 (1), 31-38. doi: http://doi.org/10.1080/0264041031000140536

5. Burke, L. M., Hawley, J. A., Wong, S. H. S., Jeukendrup, A. E. (2011). Carbohydrates for training and competition. Journal of Sports Sciences, 29 (sup1), S17-S27. doi: http://doi.org/10.1080/ 02640414.2011 .585473

6. Louise, M., Burke, O. M. (2020). Nutrition for sport and physical activity. Present Knowledge in Nutrition. Vol. 2: Clinical and Applied Topics in Nutrition. Academic Press, 101-120. doi: http:// doi.org/10.1016/b978-0-12-818460-8.00006-x

7. Dal-Ré, R. (2021). Clinical Equipoise in COVID-19 Vaccine Candidates Trials. The Journal of Clinical Pharmacology. doi: http:// doi.org/10.1002/jcph.1868

8. Dal-Ré, R. (2021). US FDA erratic approach to placebo-controlled trials after issuing an emergency use authorization for a COVID-19 vaccine. Vaccine, 39 (8), 1180-1182. doi: http:// doi.org/10.1016/j.vaccine.2021.01.050

9. Yashchur, M. (2016). Results of introduction of the program correction of morphofunctional parameters of gymnasts for aged of 14-17 years into consideration the nutritional status. Lvivskyi derzhavnyi universytet fizychnoi kultury «Naukovyi chasopys NPU» imeni M. P. Drahomanova, 3 (72), 162-165. Available at: http://enpuir.npu.edu.ua/bitstream/123456789/13965/1/ Yaschur.pdf

10. Usychenko, V. V., Byshyvets, N. I. (2010). Dosvid vykorystannia baz danykh pry rozrobtsi kompiuternoi prohramy «Atlet» dlia sportsmeniv yaki spetsializuiutsia z bodydildinhu. Teoriia $i$ metodyka fizychnoho vykhovannia $i$ sportu, 3, 67-70.

11. Yashchur, M. (2009). Rozrobka informatsiinoi tekhnolohii «Test ratsionalnoho kharchuvannia» dlia otsinky faktychnoho kharchuvannia sportsmeniv ta yoho korektsii. Teoriia $i$ metodyka fizychnoho vykhovannia $i$ sportu, 2, 112-116.

12. Hrabchenko, A. I., Fedorovych, V. O., Harashchenko, Ya. M (2009). Metody naukovykh doslidzhen. Kharkiv: NTU «KhPI», 142 Available at: https://core.ac.uk/download/pdf/159817923.pdf

Yana Biletska, PhD, Associate Professor, Department of International Ecommerce and Hotel and Restaurant Business, V. N. Karazin Kharkiv National University, Kharkiv, Ukraine,e-mail:ya.belecka@karazin.ua, ORCID: https://orcid.org/0000-0001-8060-6579

Valeriia Papakina, Department of International Ecommerce and Hotel and Restaurant Business, V. N. Karazin Kharkiv National University, Kharkiv, Ukraine, e-mail: papakinalera99@gmail.com, ORCID: https://orcid.org/0000-0001-9389-3343

Natalia Danko, PhD, Associate Professor, Department of International Ecommerce and Hotel and Restaurant Business, V. N. Karazin Kharkiv National University, Kharkiv, Ukraine, e-mail: n.danko@karazin.ua, ORCID: https://orcid.org/0000-0002-2977-6641

Larisa Grigorova-Berenda, PhD, Associate Professor, Department of International Economic Relations, V. N. Karazin Kharkiv National University, Kharkiv,Ukraine, e-mail: grigorova@karazin.ua, ORCID: https://orcid.org/0000-0002-8091-4333 